\title{
Characteristics of Polymer Concrete from Pumice Stone and Rubber Thread Waste with Polyurethane as Natural Bonding
}

\author{
Fauzi $^{1}$, Tamrin ${ }^{2}$, Anwar Dharma Sembiring ${ }^{1}$, Ridwan Abdullah Sani $^{3}$ \\ ${ }^{1}$ Department of Physics, North Sumatera University, Medan, Indonesia \\ ${ }^{2}$ Department of Chemistry, North Sumatera University, Medan, Indonesia \\ ${ }^{3}$ Department of Physics, State University of Medan, Medan, Indonesia \\ Email address: \\ Fauziman55@gmail.com (Fauzi)
}

\section{To cite this article:}

Fauzi, Tamrin, Anwar Dharma Sembiring, Ridwan Abdullah Sani. Characteristics of Polymer Concrete from Pumice Stone and Rubber Thread Waste with Polyurethane as Natural Bonding. American Journal of Physical Chemistry. Vol. 5, No. 2, 2016, pp. 26-34. doi: 10.11648/j.ajpc.20160502.12

Received: March 1, 2016; Accepted: March 15, 2016; Published: March 29, 2016

\begin{abstract}
In this study, the aggregate of polymer concrete is made using pumice stone, sand, solid waste rubber thread, and polyurethane as a binder. Variation of composition of sand and pumice are (1: 1) or (50 g: $50 \mathrm{~g})$; solid waste rubber thread are $(0,2,4,6,8,10) \%$ of the total weight of sand and pumic; while composition variations of polyurethane are $(10,15,20) \%$ of the total weight of sand and pumice. The measured parameters of samples are density, water absorption, porosity, compressive strength, impact strength, flexural strength, microstructure analysis using Scanning Electron microscope (SEM), XRD analysis and sound absorption coefficient. Based on this research, it is showed that the optimum conditions of fabricated polymer concrete characteristics are with density of $1.67 \mathrm{~g} / \mathrm{cm}^{3}$, water absorption of $13.25 \%$, porosity of $19.85 \%$, the compressive strength is $8.59 \mathrm{MPa}$, impact strength of $5.2 \mathrm{~kJ}$, and flexural strength of $50.33 \mathrm{MPa}$ ). The sound absorption coefficient of the best sample is 0.196 . This polymer concrete is lighter than conventional concrete and has better strength and sound absorption coefficient.
\end{abstract}

Keywords: Polymer Concrete, Polyurethane, Pumice Stone, Solid Waste Rubber Thread, Sound Absorption Coefficient

\section{Introduction}

Concrete materials engineering has evolved today, one of the ways in manipulation of concrete materials is using pumice agregate to obtain light concrete. In order to speed up concrete hardening time and also at the same time be able to close tight cavitiesin the concrete in order to resist high humidity it is necessary to add any polymer material (epoxy resin) in the manufacture of the concrete [1]. In addition to these advantages, the composite can attain mechanical strength of 4-5 times higher than cement concrete [2], hold the elastic modulus of the same value [3], and has good resistance and watertight [4].

An alternative adhesive (binder) of conventional cement and polymer materials have also been developed recently. Judging the performance of the materials behavior, binders possess different properties to conventional cement binder that had been used. Several types of polymer binder had been studied and found that polyuretan as epoxy resin has a relatively fast hardening time compared to conventional cement. However, both materials are able to provide good mechanical properties [5].

Pacheco et alreport the performance of concrete containing rubber tires and waste Polyethylene Terephthalate (PET), that is able to improve mechanical properties and elastic strength of the resulting polymer concrete [6]. According to Sang Ki Son et al, concrete-filled rubber tire waste is efficient to increase the deformability and energy absorption capacity of the concrete pole RFC (Rubben Filled Concrete) by considering different concrete compressive strength, size of the particles of waste rubber, and rubber content. The use of waste rubber tires for filling concrete can increase up to $90 \%$ of concrete materials. Concrete fabricated with this material may absorb 
vibration energy, so it is suitable for seismic applications (vibration) [7]. For this reason, polymer concrete is widely used in different application of civil engineering [8].

Research have been developed to study polyurethane (PU) as adhesive (binder) material in the manufacture of polymer concrete for acoustic materials. Previous research shows that the polyurethane microparticles have a tremendous effect on the absorption performance of composite materials because the microstructures and shape of the polymer microparticles of the material. Several models have been used for acoustical properties to fit the experimental results. Attenuation of sound energy in a material of polymer microparticles consist of two parts: the dense of air damping with in the pores and friction energy two sections. The dense of air damping within the pores and friction energy caused by the oscillation of the polymer particles [9].

Polyurethane has proven to be very good material as a binder in the manufacture of acoustic material. This research will used polyurethane in fabrication of lightweight concrete as a natural adhesive (binder). The polyol ingredient in the manufacture of polyurethanes are alsoused natural polyols. The fabrication of polymer concrete will use agregate of pumice and solid waste of rubber thread. Engineering utilization of solid waste of rubber thread is reuse of rubber waste.

Based on previous research of rubber waste, it is shows that the waste is no longer possible can be reused as a main ingredient in the rubber-based industry. This results makes the researcher engineered rubber waste reuse in the fabrication of polymer concrete. Under these conditions it is necessary to know the influence of the composition of pumice stone, sand and solid waste rubber thread against the concrete characteristics of the polymer by using polyurethanne as an adhesive or natural binder. The measured parameter of samples including mechanical and acoustical properties, such as: the density, water absorption, porosity compressive strength, impact strength, flexural strength, microstructure analysis using Scanning Electron Microscope
(SEM), X-ray Diffraction (XRD) and Sound Absorption.

\section{Method}

The raw materials consist of sand, pumice, solid waste rubber thread was clean and dried before treatment. Pumice was crushed and sieved together with sand using a 100 mesh sieve. The solid waste rubber thread was cut to small pieces. All of the raw materials are each weighed and mixed by adding natural adhesive polyurethane using thinner to reduce the viscosity and stirred in a container until the dough, After the mixture is evenly mixed, than it is poured into molds made of steel. There are three models of mold that shapes the beam $(10 \times 2 \times 1 \mathrm{~cm})$, cylindrical shape (diameter $2.5 \mathrm{~cm}$ and height $10 \mathrm{~cm})$, ring shape $(3 \mathrm{~cm}$ in diameter and $6 \mathrm{~mm}$ thick). The process of drying and hardening of the sample is using hot pressed at 5 tons with a temperature of $170^{\circ} \mathrm{C}$ for 30 minutes using a Universal Testing Machine Sc-2DE.

The polymer concrete samples then soaked in water for 24 hours. Further testing includes density characterization based on ASTM C.134-95, water absorption characterizen refers to ASTM. C. 20-93, porosity characterization refers to the ASTM C.237-88, compressive strength based on ASTM C.39-01, flexural strength refers to the ASTM C.348-97, coefficient sound absorption based on ASTM C.243 and ISSO 11654 . The equipments used in the characterization of mechanical compressive strength test using a Standard Test Method for hydraulic press Test Systems model HPTS.0001.08, and flexural strength using the tool Flexural Standard Test Method for Strength of Cement Mortar Hydraulic Tokyo Testing Mechanical. The microstucture was stadied by Scanning Electron Microskope (SEM Hitachi S4100), X-ray diffractormeter (XRD, RINT-Rigaku) with a $\mathrm{Cu}-\mathrm{K} \alpha$ radiation was used for phase indentification and analyzing crystallographic structure. Test sound absorption coefficient using a JISA 1416 Impedance Tube B \& K 4206, Small Tube.

Table 1. The composition of the mixture of raw materials in the manufacture of polymer concrete.

\begin{tabular}{cclllll}
\hline Samples Code & Sand $(\mathbf{g})$ & Pumice $(\mathbf{g})$ & Waste Rubber Thread (g) & Natural polyurethane (g) & Thinner $(\mathbf{g})$ \\
\hline & $\mathrm{A}_{1}$ & 50 & 50 & 0 & 10 & 5 \\
& $\mathrm{~A}_{2}$ & 49 & 49 & 2 & 10 & 5 \\
$\mathrm{~A}$ & $\mathrm{~A}_{3}$ & 48 & 48 & 4 & 10 & 5 \\
& $\mathrm{~A}_{4}$ & 47 & 47 & 6 & 10 & 5 \\
& $\mathrm{~A}_{5}$ & 46 & 46 & 8 & 10 & 5 \\
& $\mathrm{~A}_{6}$ & 45 & 45 & 10 & 10 & 5 \\
& $\mathrm{~B}_{1}$ & 50 & 50 & 0 & 15 & 7,5 \\
& $\mathrm{~B}_{2}$ & 49 & 49 & 2 & 15 & 7,5 \\
$\mathrm{~B}$ & $\mathrm{~B}_{3}$ & 48 & 48 & 4 & 15 & 7,5 \\
& $\mathrm{~B}_{4}$ & 47 & 47 & 6 & 15 & 7,5 \\
& $\mathrm{~B}_{5}$ & 46 & 46 & 8 & 15 & 7,5 \\
& $\mathrm{~B}_{6}$ & 45 & 45 & 10 & 15 & 7,5 \\
& $\mathrm{C}_{1}$ & 50 & 50 & 0 & 20 & 10 \\
& $\mathrm{C}_{2}$ & 49 & 49 & 2 & 20 & 10 \\
$\mathrm{C}$ & $\mathrm{C}_{3}$ & 48 & 48 & 4 & 20 & 10 \\
& $\mathrm{C}_{4}$ & 47 & 47 & 6 & 20 & 10 \\
& $\mathrm{C}_{5}$ & 46 & 46 & 8 & 20 & 10 \\
& $\mathrm{C}_{6}$ & 45 & 45 & 10 & 20 & 10 \\
\hline
\end{tabular}


The procedure of sample preparation is as follow: weighed the raw materials, mixed and stirred the raw materials in a container until evenly, slurry mixed poured into molds which is made of steel (steel mold). There are three shapes of samples: cylindrical shape (diameter of $2.5 \mathrm{~cm}$ and $10 \mathrm{~cm}$ thickness), blocks (10 $\mathrm{cm} \times 2 \mathrm{~cm} \times 1 \mathrm{~cm})$, and ring shape (diameter of $3 \mathrm{~cm}$ and thickness of $6 \mathrm{~mm}$ ). The next process is drying pressed the materials in a hot compressor with temperature of $170^{\circ} \mathrm{C}$ for 30 minutes. After that, the samples are characterized, to obtain the density, water absorption, porosity, compressive strength, impact strength, flexural strength, micro structure analysis, x-ray diffraction and absorption of sound.

\section{Results and Discussion}

\subsection{Density Testing}

The density of the sample are analyzed refers to the standard ASTM C134-95using the following equation:

$$
\rho_{p c}=\frac{\mathrm{M} k}{\mathrm{M} k-(M s g-M k p)} \mathrm{x} \rho \text { water }
$$

Where:

$\rho_{\mathrm{pc}}=\operatorname{density}\left(\mathrm{g} / \mathrm{cm}^{3}\right)$

$\mathrm{Mkp}=$ mass of wire $(\mathrm{g})$

Msg $=$ mass of samples in water $(\mathrm{g})$

$\mathrm{Mk}=$ mass of dry sample $(\mathrm{g})$

Result of density measurement of polymer-based concrete of sand, pumice and solid waste rubber thread materials.

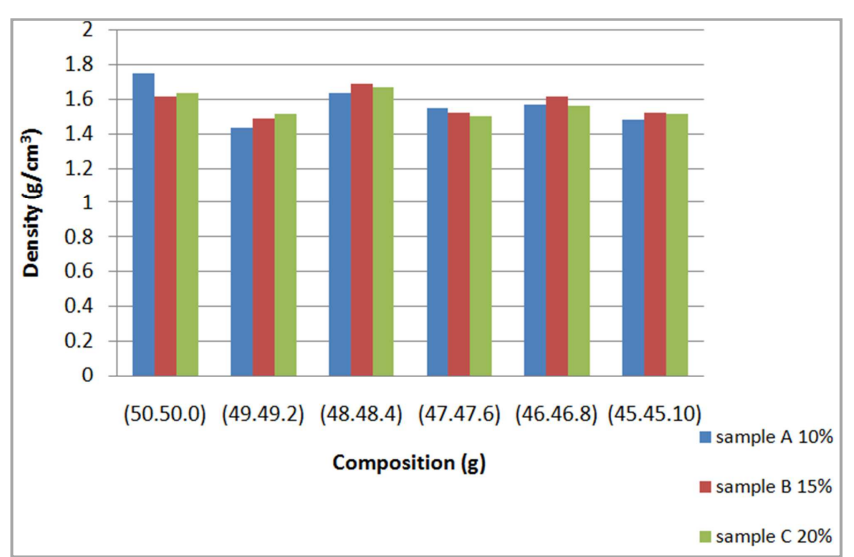

Fig. 1. Relationship between the concrete density and composition of sand, pumice and solid waste rubber thread.

Fig. 1 shows the density of polymer concrete is in the range of 1.48 to $1.75 \mathrm{~g} / \mathrm{cm}^{3}$. From the graph it can be shown that the addition of 2 gram solid waste rubber thread i.e. the composition (49: 49: 2), cause decreased of the density to $1.48 \mathrm{~g} / \mathrm{cm}^{3}$. The condition is possibly cause by unhomogen reaction of raw material of the concrete. The highest density value of $1.69 \mathrm{~g} / \mathrm{cm}^{3}$ was obtained with the composition of (48: 48: 4). This results shows that the solid waste rubber thread which behave as filler greatly affect the inter-atomic particle within the pores when the binding occur. The best composition is obtain using proportion of (48: 48: 4) with $10 \%, 15 \%$ and $20 \%$ of the total weight polyurethane. This is may be due to pumice behavior that tend to absorb compared to solid waste polyurethane rubber thread. Generally the conventional concrete (portland cement) density is about $2.307 \mathrm{~g} / \mathrm{cm}^{3}$ and pumice cement is about $1.81 \mathrm{gr} / \mathrm{cm}^{3}$ [10].

According to Satyarno, the lightweight concrete blocks based on weight distribution of pumice (density) 240-800 $\mathrm{kg} / \mathrm{m}^{3}$ has been used as a dividing wall or insulation wall, while the density of $1400 \mathrm{~kg} / \mathrm{m}^{3}$ is used as a loadbearing wall, and density of $1400-1800 \mathrm{~kg} / \mathrm{m}^{3}$ can be used as a normal brick structure [11]. Another references classified that the porous concrete block is categorized as a light brick that has a density less than $1 \mathrm{~g} / \mathrm{cm}^{3}$ [12].

\subsection{Water Absorption}

Water absorption values reflect the ability of the test specimen to absorb water after being soaked for 24 hours. The water absorption of the samples is in the ranged of $5.41 \%$ to $13.5 \%$. The water absorption of the sample are analyzed refers to the standard ASTM C134-95using the following equation:

$$
\text { Water Absorption }(\mathrm{WA})=\frac{\mathrm{Mb}-\mathrm{Mk}}{\mathrm{Mk}} \times 100 \%
$$

Where:

WA $=$ Water Absorption (\%)

$\mathrm{M}_{\mathrm{B}}=$ Sample mass after immersion in water $(\mathrm{g})$

$\mathrm{M}_{\mathrm{k}}=$ Dry mass of the sample $(\mathrm{g})$

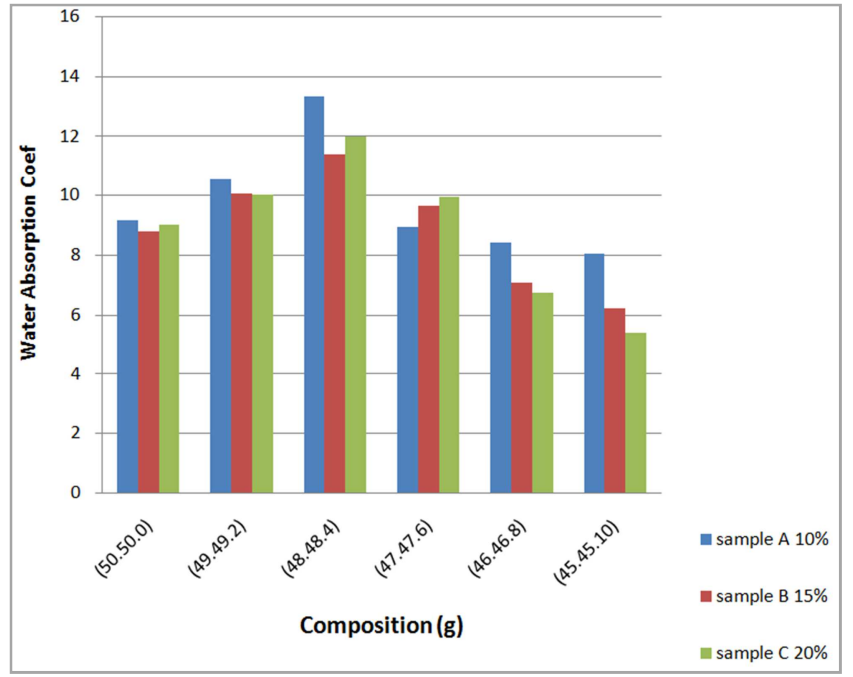

Fig. 2. Absorption of water by the polymer concrete samples varied by composition of rwa materials.

From fig. 2, it can be shown that the addition of solid waste rubber thread of 4 gram in composition of (48: 48: 4) increase water absorption value to $13.35 \%$. This condition is due to growing of the pores between atoms. Additional addition of solid waste rubber thread up to 10 grams, with the composition (45: 45: 10) and polyurethane $20 \%$ of the total weight of polymer concrete absorption, results in decreasing 
of water absorption to $5.41 \%$. This condition is due to the smaller pores in the sample. The amount of polyurethane resin propagated in the sample greatly affect the value of water absorption in the polymer concrete. This is due to the presence of natural polyurethane as a binder so that the pores of the concrete polymer gets smaller [13]. If the water absorption in polymer concrete is getting smaller, the sample is increasingly impermeable polymer concrete (resistance) and improved quality.

More contain of solid waste rubber thread cause less water absorption in the sample. This condition is caused by the closing of pores on the sample. The solid waste rubber thread also serves as an adhesive or unifier between pumice stone structure with sand, so that cavities contained in a sample can be minimized. Less water absorption related to less cavity contained in the sample. Other researchers produce samples with water absorption of $7.84 \%$, related to the pumice concrete cement manufactured from a mixture of cement, sand and pumice with hardening in the open-air [14]. While conventional concrete generally has a water absorption value of $5.5 \%$ [1].

\subsection{Porosity Testing}

The porosity of samples was analyzed refer to ASTM C.237-88, with involeves the following equation:

$$
\mathrm{P}=\frac{(\mathrm{Mb}-\mathrm{Mk})}{\mathrm{Vb}} \times \frac{1}{\rho \mathrm{w}} \times 100 \%
$$

Where:

$\mathrm{P}=$ Porosity

$\mathrm{M}_{\mathrm{b}}=$ mass of saturated sample after immersion ( $\mathrm{g}$ )

$\mathrm{M}_{\mathrm{k}}=$ dry mass of the sample after immersion $(\mathrm{g})$

$\mathrm{V}_{\mathrm{b}}=$ volume of specimen $\left(\mathrm{cm}^{3}\right)$

$\rho_{\mathrm{w}}=$ density of water $\left(\mathrm{g} / \mathrm{cm}^{3}\right)$

The relationship between porosity with the polymer concrete compositions are shown in Figure 3.

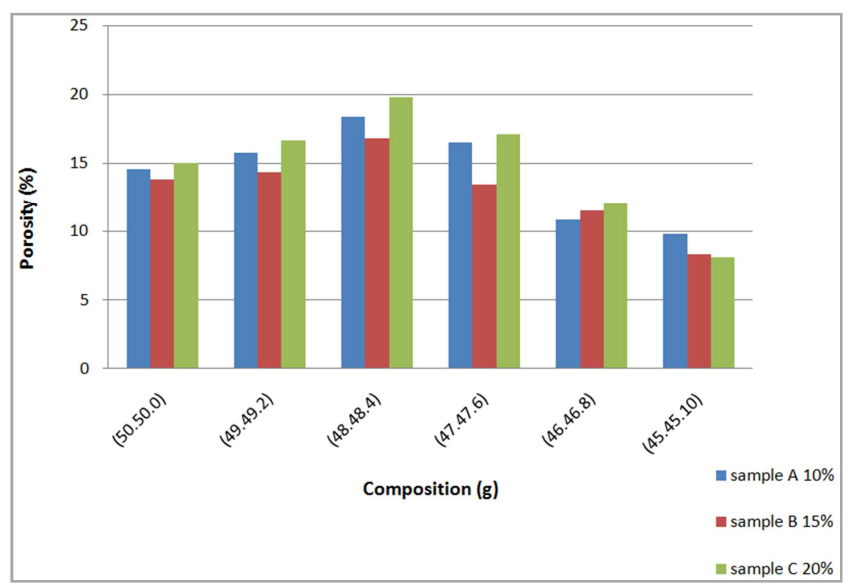

Fig. 3. Relationship between sample porosity and composition of sand, pumice and solid waste rubber thread.

The relationship between porosity with the polymer concrete compositions are shown in Figure 3. The porosity of the polymer concrete samples ranges from $8.1 \%$ to $19.85 \%$, with composition of (49: 49: 2) to (48: 48: 4). More contain of solid waste rubber thread, i.e. composition of $(47: 47: 6)$ to (45: $45: 10)$ have smaller porosity value, which is $16.8 \%$ to $8.1 \%$. This condition is happen because rubber cover the pores and provide stronger atomic bonding. Addition of polyurethane cause reduction of porosity because polyurethane fill the pores and closing micro defects in the polymer concrete. Other researchers have reported porosity of $7.84 \%$ of concrete polymer manufactured from pumice aggregate and epoxy resin with a dry oven treatment [14].

\subsection{Compressive Strength}

The compressive strength of the samples is analyzed refers to ASTM C.39-01 with include the following equation:

$$
\mathrm{P}=\frac{F}{A}
$$

where:

$$
\begin{aligned}
& \mathrm{P}=\text { Pressure }\left(\mathrm{N} / \mathrm{m}^{2}\right) \\
& \mathrm{F}=\text { Force }(\mathrm{N}) \\
& \mathrm{A}=\operatorname{area}\left(\mathrm{m}^{2}\right)
\end{aligned}
$$

The relations of polymer concrete compressive strength with the materials composition is shows in Figure 4. The compressive strength is from0.88 to $11.75 \mathrm{MPa}$. From Figure 4 , it appears that with addition of solid waste rubber thread cause great influence to reduction of compressive strength. The compressive strength will increase if the polyurethane is added, which result from stronger ties of the sand, pumice, and solid waste rubber thread. Optimum conditions are achieved with the composition of (49: 49:2) and the related compressive strength is $8.59 \mathrm{MPa}$. In the previous research, normal concrete with the addition of $5 \%$ by weight of the polyethelen polymer have a compressive strength of 23.3 $\mathrm{MPa}$ [15]. Another researcher have reported polymer concrete properties with compressive strength of 0.35 to 7 $\mathrm{MPa}$ which was used as a dividing wall or wall insulation, compressive strength of 7 to $17 \mathrm{MPa}$ is used as a loadbearing wall, and compressive strength more than $17 \mathrm{MPa}$ is used as a normal concrete structures. The classification is with variations of $10 \%, 15 \%$ and $20 \%$ polyurethane including wall insulation and wall bearers.

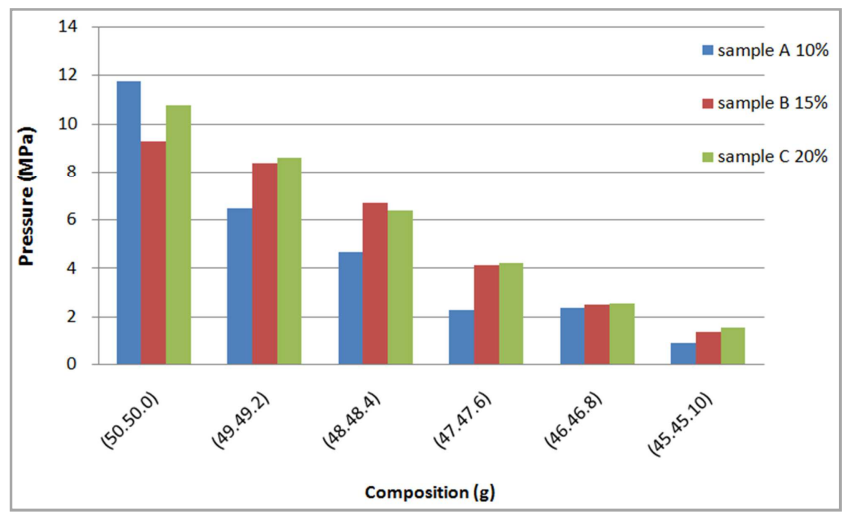

Fig. 4. Relationship of polymer concrete compressive strength composition of sand, pumice and solid rubber thread waste. 


\subsection{Impact Strength}

The impact strength of the samples is analyzed refers to ASTM C.256 with include the following equation:

$$
\mathrm{T}=\frac{E_{a b}}{A}
$$

Where:

$\mathrm{T}=$ Impact strength $\left(\mathrm{J} / \mathrm{m}^{2}\right)$

$\mathrm{E}_{\mathrm{ab}}=$ Energy absorption $(\mathrm{J})$

$\mathrm{A}=$ Area $\left(\mathrm{m}^{2}\right)$

Strong relationships of impact strengh of polymer concrete with raw materials compositions are shown in Figure 5. Impact strength of the samples ranged from 0.70 to 5.2 $\mathrm{KJ} / \mathrm{m}^{2}$. From Figure 5, it is appears the addition of solid waste rubber thread greatly affect the ability of the object receiving the maximum pressure with the composition of (45: 45: 10) which is $5.2 \mathrm{KJ} / \mathrm{m}^{2}$, and minimum compressive strength of $0.70 \mathrm{KJ} / \mathrm{m}^{2}$ with composition of (49: 49: 2). In other words, solid waste rubber and polyurethane provide greater impact strength because polyurethane has a good ability to bond the raw materials so it become tough material. This results is also agree with some research of natural binder (natural bonding) using natural rubber which concluded that the natural binding can improve the mechanical properties of material due to physical or chemical interaction between the two components or more [16].

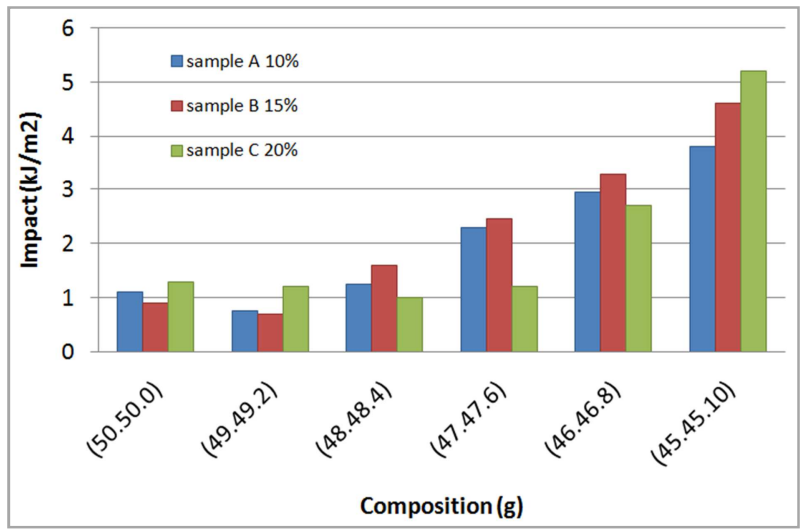

Fig. 5. Relationship between impact strength with composition of sand, pumice and waste rubber.

\subsection{Flexural Strength}

The flexural strength of the samples is analyzed refer to ASTM C.348-97with include the following equation:

$$
\mathrm{UFS}=\frac{3 P L}{2 B D^{2}}
$$

where:

$\mathrm{UFS}=$ flexural strength $\left(\mathrm{N} / \mathrm{m}^{2}\right)$

$\mathrm{B}=$ width of the sample $(\mathrm{m})$

$\mathrm{P}=$ Applied Force $(\mathrm{N})$

$\mathrm{c}=$ thickness of the sample $(\mathrm{m})$

$\mathrm{L}=$ distance between the two fulcrum (m)

Relation of flexural strength of the polymer concrete compositions is shown in Figure 6.

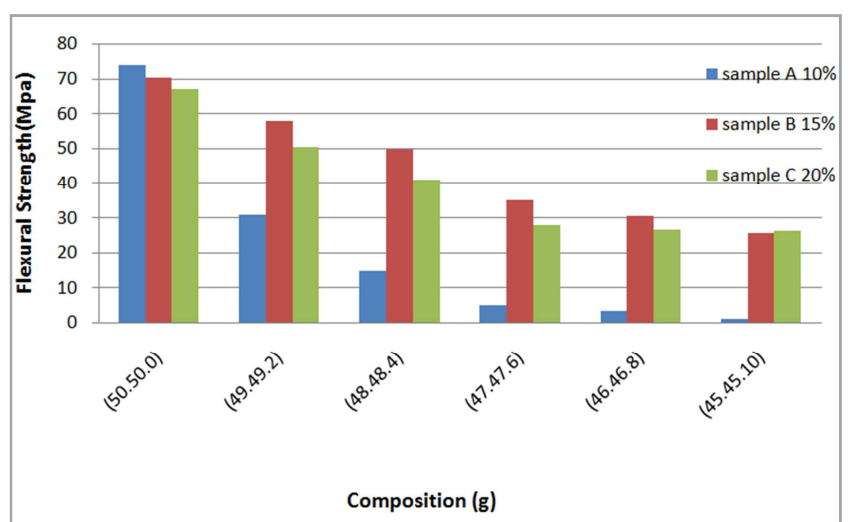

Fig. 6. Relationship between flexural strength with composition of sand, pumice stone and waste rubber.

The flexural strength of polymer concrete samples is in the ranged of 1.24 to $73.97 \mathrm{MPa}$. From Figure 6, it can be seen that more contain of sand and pumice result in increasing of the flexural strength. The flexural strength is decreases if solid waste rubber thread is added, and also decrease with the addition of polyurethane. This condition is happen because solid waste rubber thread have elastomeric properties, so more solid waste rubber thread related to smaller flexural strength [17]. The graph shows the value of flexural strength of polymer concrete with maximum value of $73.97 \mathrm{MPa}$ with composition of (50:50: 0 ) and 10\% polyurethane of the total weight, and minimum flexural strength of $1.24 \mathrm{MPa}$ with composition of (45: 45: 10) with $10 \%$ polyurethane. This suggests that reducing bond elements or aggregates can also reduced the ability of the adhesive and results of lower bonds between the particles. The homogeneity of the polymer blend of polyurethane resin is also increase the flexural strength, because the polyurethane resin will easily flow and fill the existing cavity or covering the defective parts (micro crack) that result of addition of flexural strength. The maximum flexural strength of this research sample is larger compared to conventional concrete flexural strength of about $2.5 \mathrm{MPa}$ [18]. Semi Polymer concrete have flexural strength of 14 $\mathrm{MPa}$ [19], which is relatively much smaller than the value obtained in polymer concrete.

\subsection{Analysis of Microstructure}

Microstructure analysis of polymer concrete in Figure $7 \mathrm{a}$ with the composition of (48: 48: 4) with a $10 \%$ polyurethane seen a lot of dark colors related to cavities on the sample. Irregular shape of the cavity is not distributed evenly, and clumps of aggregates (sand, pumice and solid waste rubber thread polyurethane) is seem white in color. Figure $7 \mathrm{~b}$ is SEM of sample with composition of (48: 48: 4), which 15\% polyurethane that fill the cavities that exists between grains and cover the pores in the polymer concrete. Figure $7 \mathrm{c}$ is SEM of sample with composition of (48: 48: 4) and 20\% polyurethane that also cover pores. The addition of polyurethane can cover the pores and micro defects in the polymer concrete which are formed due to the large gap between micro-filler material that tends to cause the pores. 


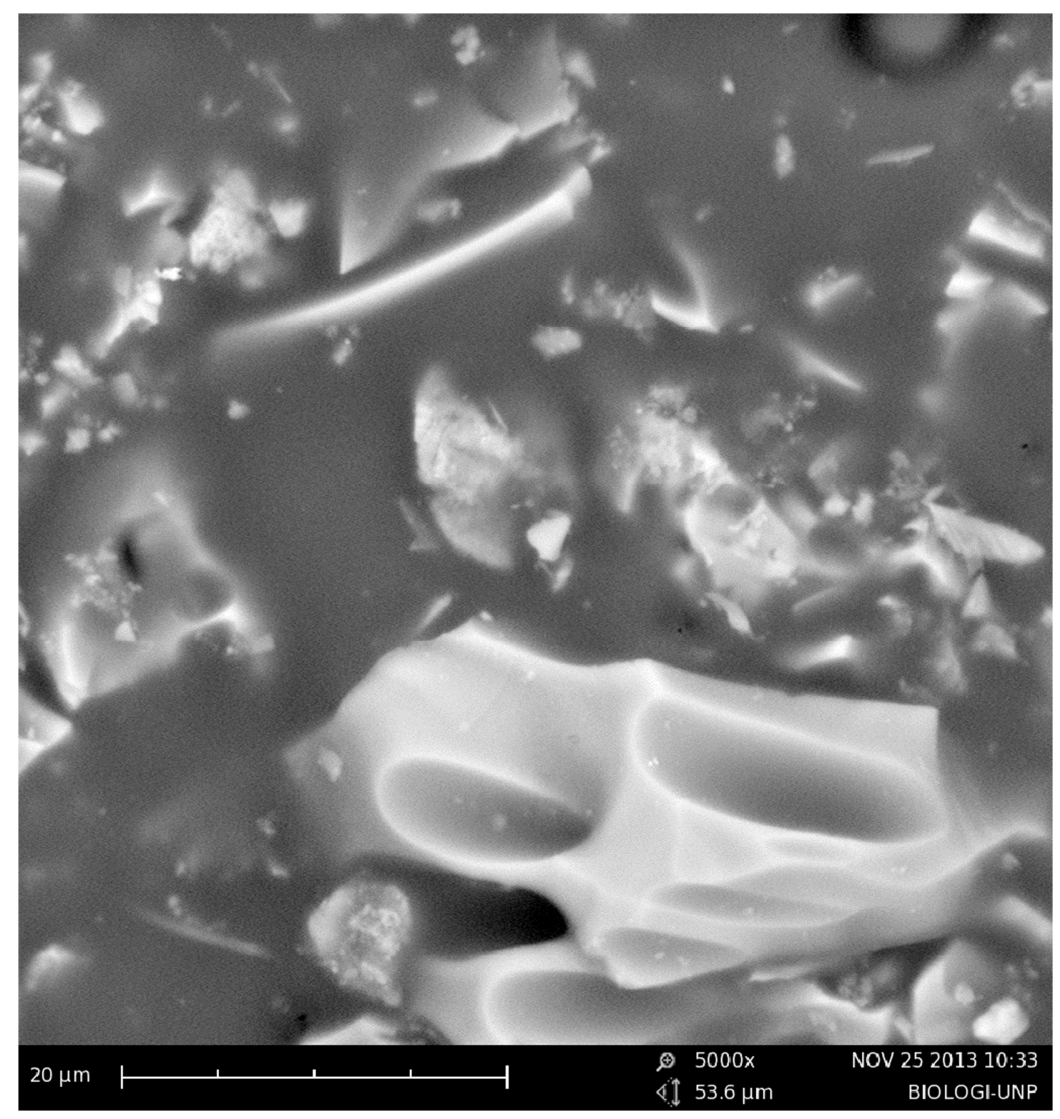

(a)

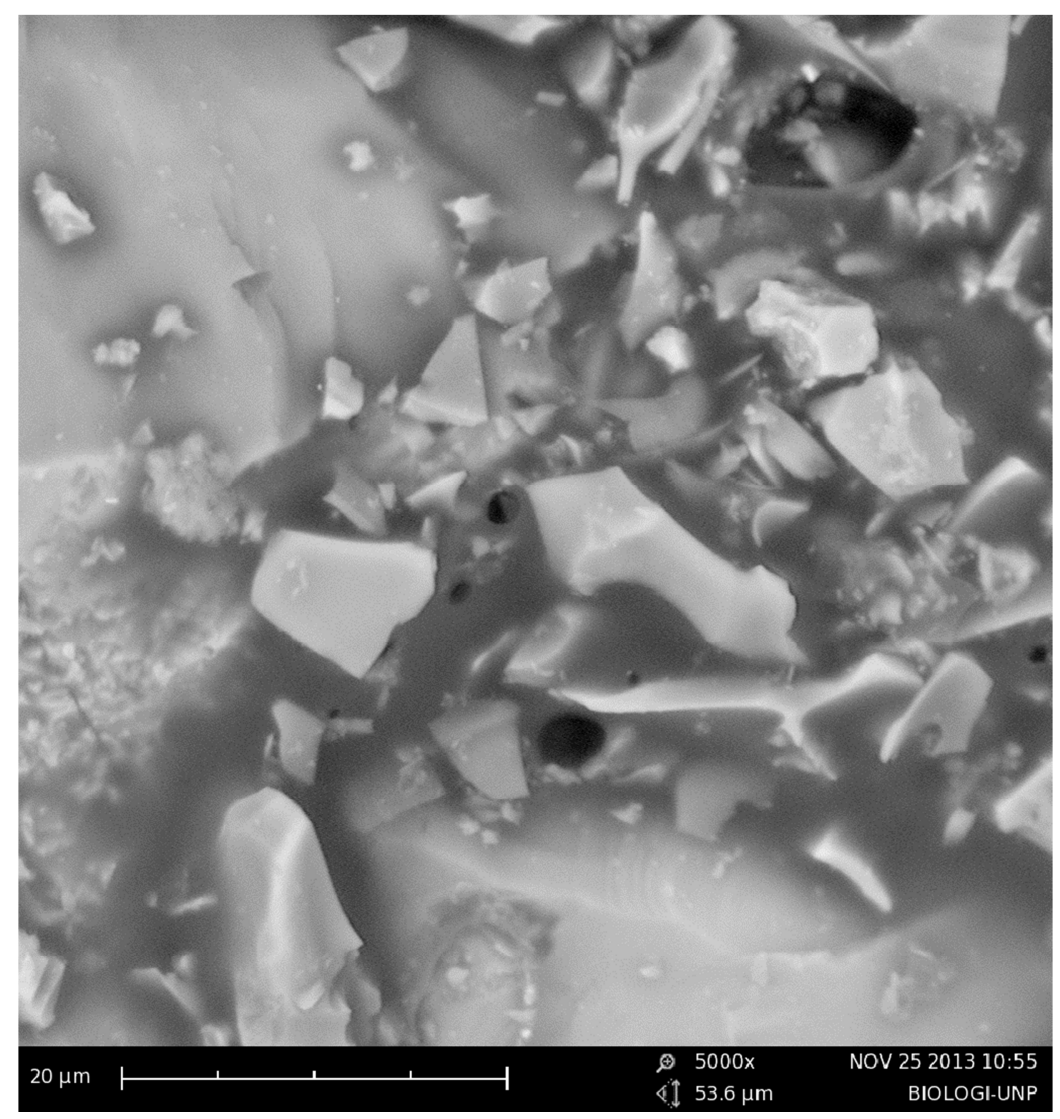

(b) 


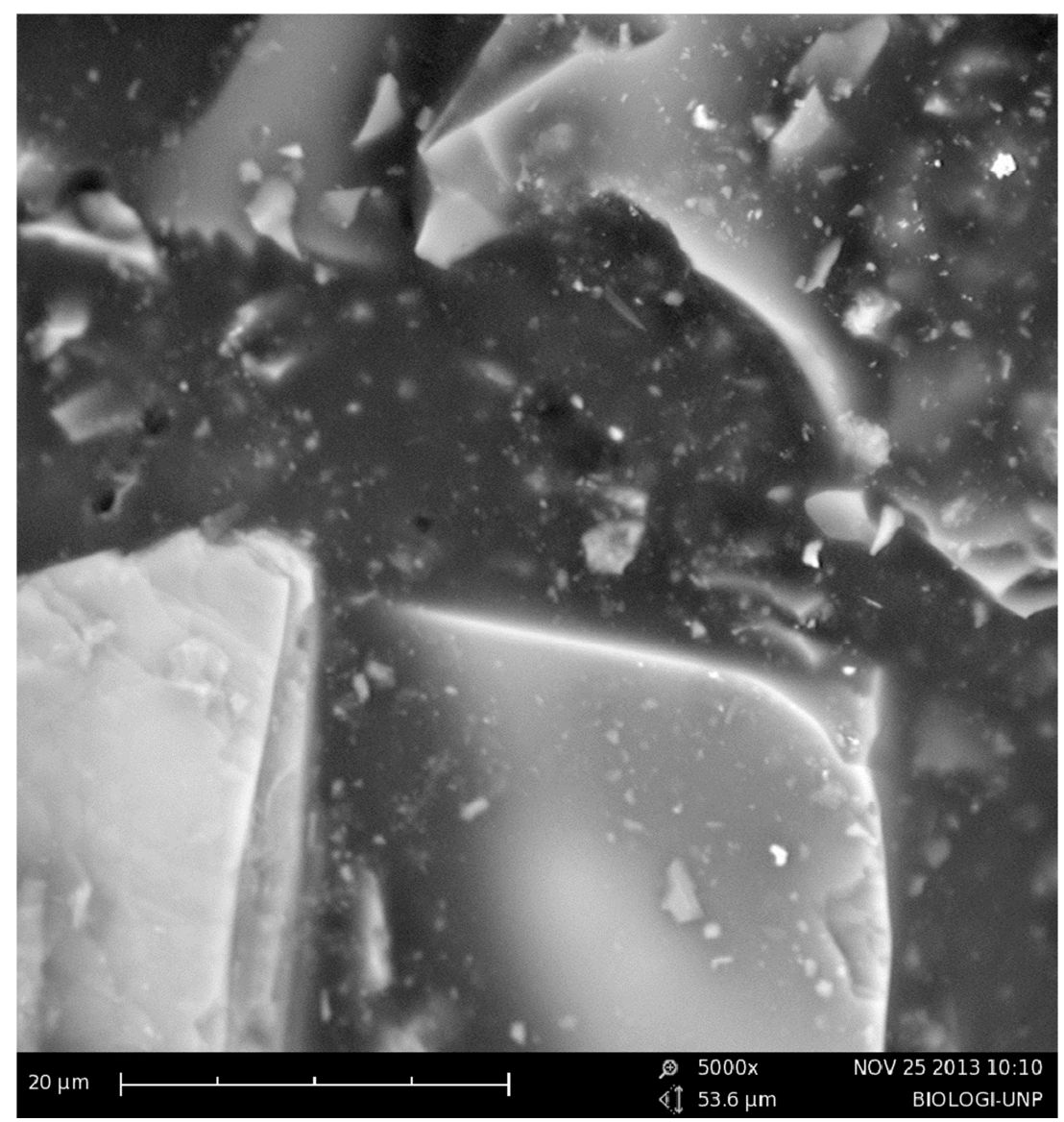

(c)

Fig. 7. SEM photograph of polymer concrete of composition (48: 48: 4), polyurethanes with (a. 10\%, b. 15\%, 20\%).

\subsection{Analysis of the X-ray Diffraction}

Analysis of polymer concrete composite structures (sand, pumice, solid waste rubber thread) is identified using X-ray difraction analysis X-ray diffraction pattern of polymer concrete with composition of (48: 48: 4) with $20 \%$ polyurethane is shows in Figure 8.

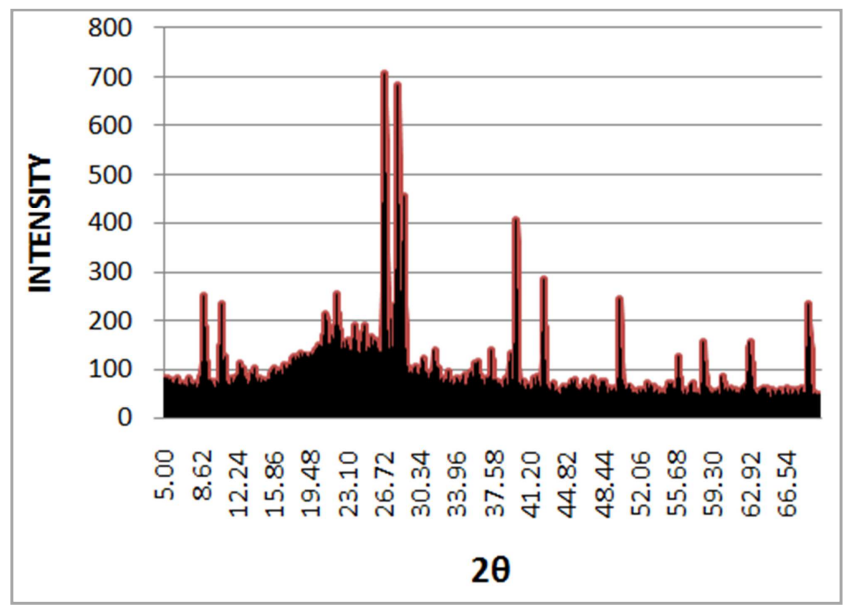

Fig. 8. X-ray diffraction pattern of polymer concrete 20\%polyurethane and (48: 48: 4) composition.

The X-ray diffraction pattern shows that several high peaks are identified. The XRD pattern of polymer concrete with $20 \%$ polyurethane, shows peak that belong to the sand (quartz) with atomic distance of $4.22 \AA, 3.32 \AA, 2.40 \AA, 2$. $29 \mathrm{~A}, 1.82 \AA$ and $1.64 \AA$. Another peaks are belong to pumice

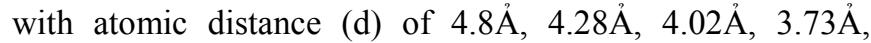

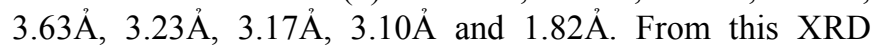
pattern, it can be concluded that the polymer concrete is a composite with constituent materials that contained sand and pumice stone of hexagonal crystals shaped. However, the solid waste rubber thread are amorphous which contribute to the background.

\subsection{Sound Absorption}

The absorption of the sample are analyzed refers to the standard ASTM C134-95using the following equation:

$$
\alpha_{\mathrm{n}}=1-\mathrm{R}=\frac{1-\mathrm{Ir}}{\mathrm{Ii}}
$$

Where:

$\alpha_{\mathrm{n}}=$ Sound Absorption Coefficient

$\mathrm{R}=$ Coefficient of reflection

$\mathrm{I}_{\mathrm{i}}=$ The intesity of the incoming sound

$\mathrm{I}_{\mathrm{r}}=$ Intensity of reflection

Sound absorption coefficient with different frequency is shows in Figure 9. The measurement of sound absorption is standardized using ISO 11654 and ASTM C.384 [20], [21]. 
Three sample with different polyurethane contain is compared in the analysis.

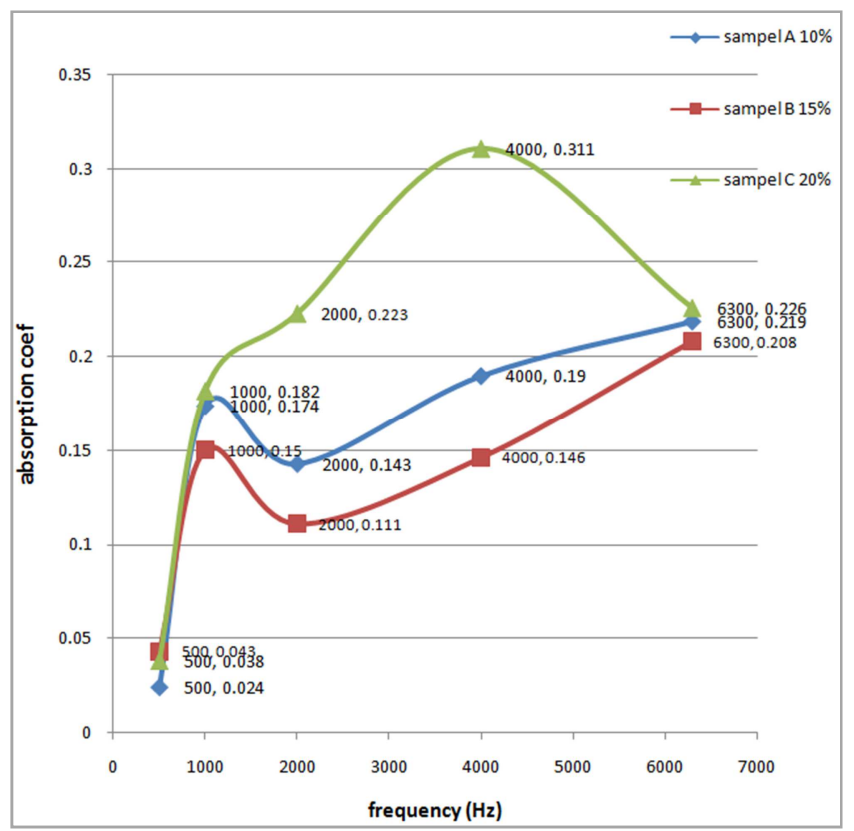

Fig. 9. Sound absorption of the polymer concrete.

Sample $\mathrm{A}_{3}(48,48,4)$ with $10 \%$ polyurethane of the total weight of the sample, have a low sound absorption properties. The distribution of aggregates and filler of sample $\mathrm{A}_{3}$ are not homogen as shows by SEM image, which is consistent with the average sound absorption coefficient of 0.159 samples with a frequency of $500 \mathrm{~Hz}$ to $6300 \mathrm{~Hz}$. Significant different of sound absorption of the three samples with a mixture of polyurethane $10 \%, 15 \%, 20 \%$ indicated that the particle formation is not homogeneous since the sound absorption is affected by the distribution of grain size and voids in the sample. Sample $\mathrm{B}_{3}(48,48,4)$ with $15 \%$ polyurethane of the total weight of sample have few pores as analyzed using the SEM image. The condition is probably due to addition of polyurethane that fills the pores (voids) between the grains.

This structure could not absorbed sound better as shown by a low sound absorption coefficient of 0.132 in average at frequency range of $500 \mathrm{~Hz}-6300 \mathrm{~Hz}$

Sample $\mathrm{C}_{3}(48,48,44)$ with $20 \%$ polyurethaneal most have no pores as analyzed from the SEM image. The polyurethane covering most evenly the pores and micro defects on the sample, but the average sound absorption coefficient of 0.196 is quite high. This phenomemon is probably due to properties of polyurethane that could absorb sound energy.

The highest sound absorption is obtain from sample $\mathrm{C}_{3}$ with a sound absorption coefficient of 0.196 . The sample with best sound absorption is polymer concrete with $20 \%$ polyurethane, which indicate that natural polyurethane can improve noise damping properties of polymer concrete. This result shows that natural polyurethane has advantages compared to synthetic polyurethane in sound absorption. This is due to the nature of polyurethane that have other compounds contained in the lignin and react to form a polyurethane polymer network [17]. Natural polyurethane and phenolic derived compounds can increase the sound damping properties of polymer concrete.

Relationship of porosity with absorption coefficient at $4000 \mathrm{~Hz}$ frequency for composition of (48: 48: 4)

Figure 10 shows that higher porosity of polymer concrete is related with better sound absorption, due absorption of sound energy in the pores. In general, an increase of absorption coefficient is occur when polyurethane is added in the polymer concrete, but violation is observed for sample with $15 \%$ polyurethane. This condition is probably due to the formation of inhomogeneous particles sizes and voids in the sample $\left(\mathrm{B}_{3}\right)$, which cause lower absorption of sound energy. This is shown in the graph of Figure 9 between three polymer concrete samples $\left(\mathrm{A}_{3} \mathrm{~B}_{3}\right.$, and $\left.\mathrm{C}_{3}\right)$, with absorption coefficient of 0.169 for sample $A_{3}$ with a porosity of $18.45 \%$, absorption coefficient of 0.132 for sample $B_{3}$ with a porosity of $16.9 \%$, and absorption coefficient of 0.196 for sample $C_{3}$ with $19.45 \%$ porosity.

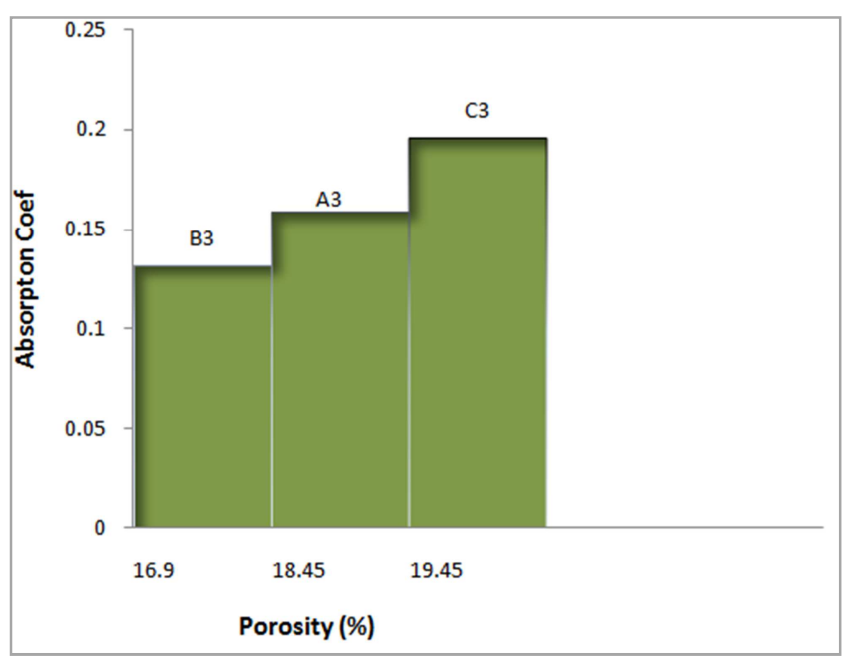

Fig. 10. Relationship of porosity with absorption coefficient.

\section{Conclusions}

The first, mechanical properties (flexural strength and compressive strength) of polymer concrete is reduced with increasing natural polyurethane as a natural binder matrix, and the impact strength is increased. Second, polymer concrete with $20 \%$ of natural polyurethane with composition of (48: 48: 4), or composition 48gr of sand, $48 \mathrm{gr}$ of pumice stone, and 4 gr of solid waste rubber thread, have small density of pores. Polymer concrete with large porosity has agreater sound absorption coefficient. Third, natural polyurethane could be used as good binder for polymer concrete with good sound absorption, as demonstrated by sound absorption coefficient of 0.196 in polymer concrete manufactured using $20 \%$ of polyurethane with composition of $48 \mathrm{gr}$ sand, $48 \mathrm{gr}$ pumice, and $4 \mathrm{gr}$ solid waste rubber thread. 


\section{Acknowledgments}

The results above, for the manufacture of polymer concrete made from a mixture of solid rubber waste are suitable for production.

This acknowledgments addressed to all parties who have helped in this work, especially to Nurdin Bukit who guided writing this article.

\section{References}

[1] A. Balaga and J. J. Beaudoin, Polymer Modified concrete, Canadian Building Digest 241, October 1985.

[2] M. Golestaneh, G. Amini, G. D. Najsfpour and M. A. Beygi. Evalution of mechanical strength of epoxy polymer concrete with silica powder as filler, World Applied Science Journal, vol 9. (2). 216-220, 2010.

[3] J. P. Gormiski, D. C. Dal Molin and C. S. Kazmierezak. Study of the modulus of elasticity of polymer concrete compounds and comparative assessment of polymer concrete and portland cement concrete, Cement and Concrete Composite Research, vol 34 (11), 2091-2095, 2004.

[4] M. E. Tawfik and S. B. Eskandar. Polymer concrete from marble wastes and recycled poly ethylene teraphthalate, Journal of Elatomers and Plastics, vol 38. (1), 65-79, 2006.

[5] E. Hady, Studi Struktur mikro pengikatan resin epoksi pada beton, Jurnal Penelitian Engineering vol. 12, 2009.

[6] F. P. Torgal, Y. Ding, S. Jalali, Properties and durability of concrete containing polymeric waste (Tyre rubber and polyethylene terephthalate bottles). Construction in Building Materials, vol 30, pp. 714-724. 2012.

[7] Ki Sang Son, Strength deformability of waste tyre rubber filled reinforced concrete columns, Construction and Building Materials, vol 25. 218-226, 2011.

[8] J. T. San-Jose, Mechanical properties in rexin polyester concrete, application to reinforced beams, Science and Engineering of Composite Material, vol 13. (4), 271-282, 2006.

[9] Gomez, Jiminez, Interpetring polymer networds based on Ctor oil polyurethane celluase derivatives and polycrycid, Latin American Applied Research, vol. 39, 131- 136, 2009.

[10] E. Yassar, Strength and thermal conductivity in light weight building materials, Bull Eng. Geol. Environ, vol. 67. 513-519, 2008.

[11] I. Styarno, Light weight styrofoam concrete for higher more ductile wall. Universitas of Gajah Mada, 2005.

[12] O. Sipirex, Autoclaved concrete block, RT Environmental Declaration, vol 1 (2) 3.23, 2000.

[13] L. H. Sperling and L. A. Utracki. Advances in Polymer Chemistry, Whasington DC, pp 231, 1994.

[14] E. Rommel, Pengaruh penambahan resin polymer terhadap perbaikan karekteristik beton dengan aggregat batu, http://diglib.gunadarma.ac.id, 1999.

[15] Y. Emilia, Pengaruh penambahan polimer jenis polyethilene terhadap tekanan beton, Politeknik Sriwijaya Palembang, 2008.

[16] C. Pelong, Physical and zology binders anti aging agents, Jurnal Fuel 97, 2012.

[17] Bilmayer, Text Book of Polymer Third edition, New York, John Willey and Son, 1994, pp. 242.

[18] P. Sebayang, Sintesa dan perekayasaan beton polimer untuk enkapsulasi limbah padat tanpa menggunakan semen, Seminar Nasional Fundenmental, Teknik Kimia, Surabaya. 2008.

[19] A. Balaga and J. J. Beaudoin. Polymer Concrete, Canadian Building. 2005.

[20] ISO 11654: Alan Truesdale Absorption Coeficients.

[21] ASTM C 384: Impedance Absorption of Acustical Materials by Impedance Tube Method. 